\title{
8. その他の委員会
}

昭和 10 年代の電気化学工業はわが国の重工業を支える基本柱の一つであつ た。先進欧米諸国の技術水準に追いつき，追い越すために必死の努力が続けら れた。そのために必要な各種の規格作成, 状況調査を行うために, また時々の 状況や国策に対応するために，本協会内に幾多の専門委員会が発足した。そし て，その任務を全うし，あるいは第二次世界大戦の終了とともに解散した。ま た，第二次大戦後の復興期に当たって重要な役割を演じた委員会もある。ここ では，それら委員会の中，現在は存在しない専門委員会について，設置された 順に簡単に紹介する。

\section{1 事業委員会}

昭和 9 年 7 月, 加藤与五郎氏（当時会長）を委員長に発足，本協会の骨子を なす事業大綱を計画することを主目的とし，歴代会長が委員長に当り，昭和 24 年度まで継続した。ちなみに, 翌 10 年 2 月, 本協会にとって初めての技術に関 わる専門委員会である，1) 鍍金規格委員会，2）電気化学工業用電力調查委員 会の設置が決議されている。

\section{2 鍍金規格調査委員会}

各種鍍金製品の品質，試験法の規格案を作成することを目的に，井上春成氏 を委員長に昭和 10 年発足した。しんちゅう基板へのニッケル鍍金製品の規格調 査はすべての鍍金規格の基本であると同時に，鍍金工業全体に及ぼす影響が大 きいところから，まずこの鍍金規格を作成することにした。当初は，しんちゅ う地金に一定条件でニッケルの電気鍍金を施したテストピースについて，1)硬 度試験，2）フェロキシル試験，3）噴霧試験，4）腐食試験，5)屈曲試験を各委員 が分担して行い，その結果を持ち寄り，協議をすることを繰り返した。結果が 一致しない場合は全員で実験を行う等, 年数回の委員会が持たれ, 当局に品質, 
試験法の案を答申した。引き続き，黄銅菜地クロム、ニッタル・クロム鍍金の 規格，電球用鉄製口金の西鉛および亜鉛一力ドミウム鍍金規格（日本電球組合

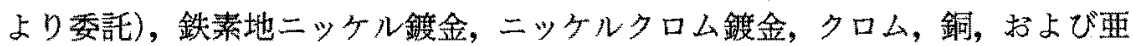
鉛鍍金規格，各種錫鍍金規格定作成した。昭和 19 年には鉏金資材の不足から， 代用品について調查研究を行い，同年度終結した。

\section{3 電気化学工業用電力調查委員会}

本委員会は昭和 10 年 2 月, 冨山 保氏を委員長に発足した。当時, 電気化学 工業はわが国を支える基盤産業であり，花形産業であった。その製品はまさに 電気の塊であり，大黨の安価で良䝷の電力供給を受けることは，本協会の一大 㸟望であった。本来, かが国の電気事業発達の沿革は照明, 招よび動力方面の 需要を满たすことから始まったために，電気事業に関する法規もとれに隼じて 制定され，電力も電灯抢よび動力用として，供給区域を定めて販売された。一 方, 後に勃興し, 急速にその需要䡒を高めてきた電気化学工業にとって, その 供給体系忏㹥なはだなじまないものであった。このような状洗下で，当時の会 長，棚橋寅五郎氏は協会誌の巻頭言で以下のことを監督官仃に要望している。

1) 化学工業の市場は絶えず変動するから,永久不畆の設備を設置するのは困 難である。したか゚って，市場の状沉に合わせて，それに必要な送電受電の設䚚 等に関する許可は簡便，迅速に取り扱って欲しい。

2) 電気化学工業用の電力注いわば製品の原料であり,極力女価な電力を大量 に必要とするから，供給区域を超越し，水力発電の際の河川の水系の異なる電 力を集中させて電力供給の調節を図って欲しい。

3）やををえず都市近郊に工場を設置せざるを得ない場合には，自家用火力発 電設備建設を認めてもらいたい。

同じ頃，重要国策の一つとして，電力事業の国営化問題が起こり，監督官庁 関係者に対応するためにも，基礎資料として電気化学工業にどの位電力が使用 されているかを把挃する必要が生じた。委員会では昭和 9 年度わよび 10 年度に おける電気化学製品各種目について生産額,製品単位当りの所要電力を調查し， 両者上り消費電力量を算出した。併せて, 当時水力発電の便から，わが国の電 
188

気化学工業の集中していた富山県における電力事業括よび電気化学工業に関わ る諸統計資料も集め，報告書を作成した(昭和 12 年 11 月)。ちなみに，当時水 の国と言わ机たわが国の水力発電能力 (昭和 9 年 12 月現在) '瑺時 2,220,000 $\mathrm{kW}$, 最大 $4,220,000 \mathrm{~kW}$ で, 発笔可能未開発水力として約 $60 \%$ を残していた。 そして, 電気化学工業に消費される電力量は工業用全電力の $40 \%$ 強を占め, き らに急上昇を続けていた。

本委員会は昭和 15 年に㹥電力委員会と改称し, 統制経済下に㧍ける電力送 電制限，電気料值上げ，深夜余剩篭力利用の許可等続発する各種問題につき， 電気庁を初め，関係当局と対応した。24 年再設置（委員長：北脇市太郎氏）さ れた。この間, 電力料金, 電力料確保, 電源開発に万全を期すよう要望し, 值 上げ問題につき，建議書を作成して関係当局に提出 (26 年), 27 年にも電気料 金再值上げに対する要望書を提出した。25 周年揢念事業 (33 年)として許画 れた募集論文 “電気化学工業の将来”でも内容が電力問題に集中し，原子力発 電実施直前の委員会の見解（委員長：佐藤止戈夫氏）功述心゙られている。その 後, 38 年 (委員長: 井上春成氏), 41 年 (委員長: 岡 俊平氏)にも電気料金值上 げに対し，電気化学工業への影響が大きいことから要望書を関係各方面に提出 した。

\section{4 電力国策問題研究委員会}

本委員会は昭和 11 年 9 月発足した（委員長：棚橋寅五郎氏）。第二次世界大 戦突入前の緊迫した状況の中で多くのことが国策として統制されようとしてい た。電力事業沈その最たるものの一つであったが, 本協会では電気化学工業八 の電力供給がどのようになるかが，大きな関心事であった。早速，第 1 回会合 には遇信省電気局監理課長藤并宗治氏を招き，電力供給に関する国策を聞き， 貿疑応答を行った。娄員会の動き牥速く，12月には電力統制強化に関して建議 書を作成し, 総理大臣, 関係各大臣, 貴族院, 衆議院議長に提出した。その趣 气は，1）民間の電気産業関係者，学識経験者からなる強力な番議会を設置し， 積極的な機能を与えて電力梳制事業の中心となり，統制が完全に行われるよう にすること，2 ) 自家発電が必要な事業に対しては, 速やかに設備設置の許可を 
与え，事業発展を助長することであった。さらにその趣旨の徹底をはかるため， 両院議員にも建議書および書状を送っている。

\section{5 カーバイド規格調査委員会}

炭化カルシウム（工業的な慣用名はカーバイド）はアセチレンの原料として 有機合成工業に用いられるほか, 石灰窒素の原料となり, 肥料, 製鋼の脱硫, 脱酸凨として用いられ，酸化マグネシウムを製造する還元剤として，用いられ たこともある。わが国では, 明治 35 年藤山常一氏により, 水力発電所のあった 仙台市三居沢の宮城電灯株式会社の一角において，その工業化が始まった。本 委員会はこの重要な電気化学工業製品であるカーバイドの規格を制定するため の調查研究機関として, 昭和 11 年設置された（委員長 : 加藤与五郎氏)。力ー バイドの塊状, 品位, 不純物, 試料採取方法, 試験方法, 再試験, 容量および 重量の各項目にわたり, 規格案を作成し, 商工省に提出した。昭和 16 年, カー バイドおよび誘導体委員会と改称し, 両委員長に亀山直人氏, 冨山保氏を各々 決めた。引続き技術方面の調查も進め, 昭和 19 年, カーバイド増産に関する建 議書および調查報告書として製造技術改善に関する具体案を提出して終了し た。

\section{6 電気化学便覧編纂委員会}

昭和 12 年, 当初電気化学ポケット編纂委員会 (委員長：亀山直人氏) として 発足, 後上記のように改称した。昭和 17 年電気化学便覧を発行した。その後, 改訂委員会が発足 (昭和 24 年, 委員長: 武井 武氏), 昭和 27 年改訂版を発行 した。さらに第 3 版（委員長：向坊 隆氏）は 39 年, 第 4 版（委員長：笛木和 雄氏）は 59 年発行された。

\section{7 電気化学製品統計調查委員会}

昭和 13 年発足 (委員長: 冨山 保氏), 昭和 10,11 年度のわが国電気化学製品 生産額, 輸出入額及び世界各国主要製品生産額を調査し, 同年度末終結した。 


\section{8 鉄合金委員会}

昭和 15 年発足 (委員長：武井 武氏)，その目的は国策に順灾し，鉄合金老電 熱的に製造する電熱治金および応用に関して，調査研究を進め，学術的並びに 技術的に進歩，発達を図ることであった。活動は文献調查を初めとして，以下 のように多岥の内容にわたっている。

1）珪素鉄について，不定時電力の有効利用法，規格の吟味，風化の防止法， 製造標準

2）マンガン鉄について，低品位鉱の有効利用法，製鋼におけるマンガン鉱の 節約，規格の吟味，珪素マンガン鉄の利用法，マンガンの分析法

3）ク口ム鉄について，鳥取産貧鉝処理法，鉣石品位低下と㷠の問題，非金属 介在物と为スに関する問題，鉱石品位低下に扔ける規格の哈味，含窒素クロム 鉱の問題

4）燐鉄製造上の技術的諸問題，原料問題

5）タングステン鉄，モリブデン鉄について,テルミット法と電気炬との比較 研究，石灭重石の利用，鉄重石を原料とする場合の規格吟味

6）バナジウム，鉄，チタン鉄製造に関する技術上の諸問題解決，低品位鉱の 開発方法

7）珪化石灰の用途沾よび製法の研栄

8）金属マンガン，金属珪素の製鉄技術

9）電気炉用炭素電極

商工省の後援を得て，東覀共栄圈内に於ける低品位鉝石の利用開発に関する 基礎的研究も進めた。

\section{9 創立 10 周年記念事業準備委員会}

昭和 16 年設置 (委員長：棚橋寅五郎氏) し，記念大会開催，会誌記念号発行， 電気化学工業発達史編纂, 眯賞論文募集, 記念奖学資金募集等を計画実行した。

\subsection{0 電気化学国土計画委員会}

大戦勃発後まもなく，本会は企画院より国土計画策定上必要な資料提供の依 
頼を受けた。早速事業委員会で協議の上、時局に鑑み国土計画に万全を期すた め, 資料作成に協力することを決め, 昭和 17 年 2 月本委員会を設置した。委 員長には時の本会会長, 北脇市太郎氏を推し, 日満, 支および南洋を含む地域 内の電気化学国土計画に関する調查, 研究, 立案することを目的とした。以下 の 7 小委員会とこれらを統括するため前会長, 前副会長, 現副会長, および各 小委員会委員長よりなる総務委員会（委員長：日比勝治氏）を設けた。小委員 会名，委員長および調查項目は以下のようであった。1)軽金属小委員会（亀山 直人氏，アルミニウム，マグネシウム)，2）曹達工業小委員会(浦野三郎氏，食 塩, 曹達灰, 苛性曹達, 塩素製品), 3) カーバイド及び誘導体小委員会 (井上春 成氏，カーバイド，石灰窒素，アセチレン誘導体)，4）窒素工業小委員会(北脇 市太郎氏, 石灰窒素, 硫安, 硫燐安)，5）電気冶金小委員会（武井 武氏, 電気 製鉄，鉄合金，錫，ニッケル，コバルト，銅，亜鉛，鉛，水銀，，6）電熱工業小 委員会 (永井彰一郎氏, アランダム, カーボランダム), 7) 電力資源小委員会 (福 田 豊氏, 電力資源)

各小委員会とも各々の担当項目について, 日満支に打りるそれら電気化学工 業としての適地調查, 立地条件 (原料, 電力, 人的資源, 用水, 土地, 他産業 との関係), 現状調査等を詳細に行い, 18 年 3 月基䃈調査報告書を企画庁に提出 した。本件は当時の本協会を挙げての一大事業であった。18 年 10 月には電気 化学工場防空小委員会 (委員長 : 日比勝治氏) が追加設置され, 電気化学工場 の防空対策につき調查を行った。

\subsection{1 本邦電気化学工業発達史編籍委員会}

昭和 17 年発足（委員長：北脇市太郎氏）したが，大戦中であり時局に鑑み事 業着手を延期した。その後, 委員会が再発足し(委員長 : 青野武雄氏), 本会創 立 25 周年記念出版として, 昭和 34 年「日本の電気工業の発展」が発行された。

\subsection{2 電気製鉄委員会}

昭和 18 年発足 (委員長：日比勝治氏), 次の 4 小委員会に分け, 東亜共栄圈 の製鉄立案に役立てるため，電気製鉄の基䃈調查を行ったが，19 年 3 月中止と 
なった。

第一小委員会（普通鉄鋼原料）小委員長：高木英吉氏，第二小委員会（砂鉄 原料）小委員長：神谷基夫氏，第三小委員会（特殊原料）小委員長：藤源唯 義氏，第四小娄員会（電解鉄鍀）小委員長：武井 武氏。

\subsection{3 電極委員会}

昭和 18 年発足（委員長：北脇市太郎氏），調查活動を開始したが，これに先 立ち，16 年関西支部主催で，電極対策協議会（座談会）が電極製造メーカ一, 使用者側代表出席のもと開かれており，アルミニウム，マグネシウム，食塩電 解，カーバイド製造用各電極として炭素電極の原料，電極の量，質などについ て論じられている。終戦とともに自然消減したが，22年事業委員会で再度設置 を承認され（委員長：武井 武氏）,カーバイド括よび石灰空素，電気製鋼，電 気製鉄，電気鋳鉄，フェロアロイ及び研磨材製造用，軽金属，アルカリ等の電 解工業用炭素質電極材料の使用規格，材料払底に対方る対応策を検討し，電極 材料の優先的輸入を関係官庁に要望した。

\subsection{4 電気製塩委員会}

終戦まもない昭和 20 年 11 月発足(委員長：日比勝治氏)，電力事情，製塩技 術向上のための調査研究，資料作成至開始したが，塩需給政策の変更により 22 年 3 月中止した。

\subsection{5 電解隔膜委員会}

昭和 22 年発足 (委員長：田中寿一氏，28 年以降，岡 俊平氏)，電解隔膜の需 要調查, 生産及び輸入調查, 品質改善, 代用品製造, 研究調查を行い, 28 年食 塩電解用石綿紙の試作研究を完了, 生産費は輸入品洒格に比し, 大幅引き下げ が予想され国際化のめどがついた。岡委員長に代わってからは，水電解，アル カリ電解，過硫酸アンモニウム製造用等各種隔膜の試験法，測定法の規格を作 成，かつ外国製品に劣らぬ石綿純隔膜試作に成功して 31 年 3 月解散した。 


\subsection{6 電解精製委員会}

金属精製技術，特にスルファミン酸塩浴を用いる鉛の電解精製に関する調査 研究を行った。鉛は各種の乾式精製法が発達してきたが，粗鉛中に蒼鉛が含ま れる場合に電解精製を必要とした。しかし，鉛の塩化物や硫酸塩は溶解度が低 いため，他の金属電解のように簡単ではなかった。戦後，文献その他でイタリ アの精鍊所での活況が伝えられ，スルファミン酸浴電解によれば錫の除去など も容易にでき, 電解液の調製と維持が容易なこと等多くの利点があるらしいこ とが伝わって来，わが国精錬所の注目を集めていた。このような状況下で本委 員会 (委員長：小川芳樹氏) は 27 年発足し，スルファミン酸塩を用いる鉛の電 解精鍊に関する調查研究を行い，その技術を確立して 29 年終了した。この間 2 回にわたり協会誌に研究報告書を発表した。

\subsection{7 ポーラログラフ委員会}

ポーラログラフィーは 1922 年，J. Heyrovsky 氏（チェコスロバキア）によ って創始され, 1924 年加電圧電流曲線を写真法により自記記録する装置が彼と その下に留学中であった志方益三氏 (京都帝大) によって発明され，翌 1925 年 ポーラログラフという名称で公表された。わが国での研究は発祥の地プラーグ に約 1 年遅れ京都で始まった。電気化学第 2 巻 (昭和 9 年 (1934 年))にもポー ラログラフ法による燐光体の分析に関する報文が見られる。ポーラログラフィ 一は戦前，戦後を通じ電気化学でわが国が理諭および応用面におういて世界をリ ードした数少ない分野のひとつであった。本委員会 (委員長：舘 勇氏）は昭和 28 年, ポーラログラフ法の基礎理論の発展と普及を目的に設置され，その運営 は関西支部に委託され，いっそう研究に拍車がかかった。会誌「ポーラログラ フィーの研究」を年 4 回発行するとともに, 日本化学会, 日本分析化学会と共 催で毎年ポーラログラフ討論会を開催した。また，外国より著名な研究者を招 待し, 各地で講演会の開催とディスカッションの実施, ポーラログラフ機器分 析講習会等も開催した。昭和 35 年, 本委員会が母体となって日本ポーラログラ フ学会が創立されたので，本委員会は発展的に解消した。 


\subsection{8 スラッグ委員会（スラグ委員会）}

精鍊冶金において溶融スラグと溶融製品との間の化学平衡，反応速度は精鍊 の基礶であり，これらを左右するスラグの物理化学的性質は精鍊品の品質と密 接な関係を持っている。精鍊の合理化にはスラグの性質を究明し，理論的考察 を行うことが重要であり，また大きな副産物であるスラグを有效に活用するこ とも重要である。このような観点から，本会は昭和 30 年，スラッグに関する基 碟的理論ならびに有効利用のための調查研究を行うことを目的に設立された (委員梫：井上春成氏)。目的別に專門部会として鉄治金(部会長：武井 武氏), 非鉄金属 (小川芳樹氏)，チタンスラダ (大我勝躬氏) の3 部会を置いた。3部 会の当初の目的怯次のようであった。

○鉄冶金部会 1) スラグに関方る外国事情の調查研究 2) スラグの物理化学的 性筫の調查研究 3) スラグの利用に関する調查研究

○非鉄金属部会 1) スラグの肥効性調查 2) 熔体スラグの物理化学的研究実施 3)非鉄スラグの利用拉上び処理に関する文献の収録

○チタンスラグ部会 1)低チタンスラグの利用研究 2)高チタンスラグの研究 スラグについての物理化学的基礎データはただらに実操業に役立てられた。 利用については妵ず，肥効性に着目して東京農業大学に委託して，水稲作拉よ び麦作に対する肥料性試験を実施した。肥料効果の現れたものが多く，中には $20 \%$ 以上堌收の見られたものもあるが，永年使用によるスラグの蓄積の植物 への影䉡等さらに今後の破究が必要との見解であった。

鉄冶金, チタン尃門部会は関連性が多けので 33 年合併して, 鉄チタン尃門部 会とし (部会長：武井 武氏)，基礎，製造，利用の 3 分科会を設けた。さらに 翌 34 年，専門部会を統合し（井上春成氏），事業目的に応じて調查小委員会， 記録小委員会，分析小委員会，酸化チタンスラグ小委員会に分けた。36年基礎 と利用上の調查研究は相当成果を見たので一応中止し，分析法の究明を目的と してスラグ分析委員会と改称した（娄員長：徳永 惊氏）。この間，酸化クロム 定量法，マンガン，タイ酸，アルミナ同時定量法，鉛定量法をはじめ多くの元 素, 化合物の湿式定量法娄確立し， 37 年解散した。 


\subsection{9 電気化学工業事情海外紹介委員会}

フランス雑誌社より日本の電気化学工業紹介号出版に関し協力を要請された のを機会に英文で紹介書を出版することになり，32 年発足した (委員長：安西 正夫氏)。編集は杉野喜一郎副委員長のもと, 通産省の補助, 各関係事業協会の 協力を得て, 33 年完成した。

\subsection{0 創立 25 周年記念事業委員会}

32 年発足 (委員長 : 岡田辰三氏, 実行委員長 : 田中東馬氏), 記念式典, 功績 者表彰の他, 記念事業として, 『日本の電気化学工業の発展」出版, 懸賞論文課 題『かが国電気化学工業の将来』, 『日本の電気化学工業の発展』出版, 海外名 著紹介等を行った。

\subsection{1 高純度金属委員会}

高純度金属の製造技術の向上を計り，その性能調查と需要面の開拓を目的と して, 32 年発足した (委員長: 小川芳樹氏，专の後，徳永 惊氏，舟木好右衛門 氏）。発足と前後して，高純度金属の製造者，使用者，学界関係者出席のもと， 高純度金属に関する座談会占催され，各分野，例えば，電子管，半導体，電磁 気材料，防蝕，航空機，耐熟材料，原子燃料，原子炻材料などに対する高純度 金属の新しい機能, 意義, 純度に対する要求が明確にされた。調査研究, 講演 会, 見学会の他, 高純度金属分析検査講習会や分析法テキストの発行がなされ, 43 年頃まで活動した。

\subsection{2 電熱化学委員会}

従来のスラグ委員会事業を含めた広範にわたる電熱化学関係事業の技術向上 を計るため，36 年設置された (委員長 : 青野武雄氏)。随時, 講演会, 講習会, 見学会を行った。電力料金の值上げに関わり，自家発電の経济性についての講 演会も行われた。39 年にはその成果を「公害問題と防歴方法の進步」として冊 子を発行した。 


\subsection{3 創立 30 周年記念事業委員会}

昭和 37 年設立 (委員長 : 武井 武氏, 実行委員長：葥藤辰雄氏), 記念事業と して，1）電気化学技能賞贈呈，2）記念大会，祝賀稂親会，3）「電気化学」記 念特集号発行，4)電気化学便覽改部等を行った。

\subsection{4 土質化学委員会}

昭和 38 年朊立（委員長：永井彰一郎氏）, 土質化学见関する調査, 講演会, 見学等を行い， 42 年頃まで活動した。 39 年，冊子「土質安定工法の諸問題」を 発行した。

\subsection{5 創立 50 周年記念事業委員会}

昭和 57 年設立 (委員曼：吉沢四郎氏, 実行委員長：高橋正雄氏), 記念事業 として，1)記念式典, 記念大会, 2)「電気化学」記念特集号発行, 3) “新しい 電気化学” 刊行，4）“若い技術者のための電気化学” 刊行，5)電気化学便覧改 訂，6)各種国際会議の開催等を行った。

\subsection{6 創立 60 周年記念事業委員会}

平成 3 年設立 (委員長 : 向坊 隆氏), 委員会の活動々記念事業は次の上うで ある。1)記念式典 (委員長：增子 鸟氏)，2）記念出版（委員長：塩川二朗氏）, 会誌記念特集号 (No.1,7), 「電気化学協会 60 年史」,「広がる電気化学」の刊行, 3) 事業企画 (委員長：清山哲郎氏), 記念大会 (春季)，93 年電気化学日米合同 大会, 記念セミナー「21世紀に挑む一一電気・電子化学の夢」, 本部括よび各支 部主催, East Asia Conference on Chemical Sensors, East Asia Symposium on Frontiers of Industry，4) 将来構想（委員長：安福眞民氏，5) 産学協力推 進 (委員長：山崎点一氏)，6)記念事業募金 (委員長：瀬谷博道氏)，7)財務 (委 員長：渡辺信淳氏) 


\section{引用文献}

1）川野邊彌一, 電気化学, 6, 361 (1938)

\section{付 記}

昭和 30 年代より，本協会の運営や対外的事業に関わる事業委員会と研究，技 術に関わる専門委員会の区別が明確になった。38 年当時, 前者に属する委員会 としては学術用語委員会, 広告委員会, 電気化学便覧編集委員会が存在した。 以後その種類は多くの数にのぼるのですべて省いた。各年代の記念事業委員会 も事業委員会のカテゴリーに入ると思われるが，資料「日本の電気化学工業の 発展」抜粋に従い, 記載した。

(高橋正雄, 佐藤咗一) 